\title{
Evaluation of Lower Urinary Tract Functions in Diabetic Patients
}

\section{Diyabetik Hastalarda Alt Üriner Sistem Fonksiyonlarının Değerlendirilmesi}

\author{
(1) Ümit Eskidemir1', (1) Adnan Şimşir², (1) Ilgın Yıldırım Şimşir³, (1) Fuat Kızılay², (1) Ceyhun Özyurt² \\ ${ }^{1}$ Menemen State Hospital, Clinic of Urology, Izmir, Turkiye \\ 2Ege University Faculty of Medicine, Department of Urology, Izmir, Turkiye \\ ${ }^{3}$ Ege University Faculty of Medicine, Department of Endocrinology and Metabolism, İmir, Turkiye
}

\section{What's known on the subject? and What does the study add?}

Diabetes mellitus is a debilitating and costly disease with multiple serious complications. Lower urinary tract complications are among the most common complications of diabetes mellitus. Although these complications such as diabetic cystopathy and diabetic bladder dysfunction are very common, there is a lack of diabetes treatment guidelines about routine evaluation of lower urinary tract functions in this patient population. Our results indicates that the subgroups of diabetic patients with emphasized risk factors require a more detailed evaluation of lower urinary tract functions and the guidelines should pay more attention on this issue.

\section{Abstract}

Objective: In this study, we aimed to investigate the effect of diabetes-related metabolic changes and chronic complications on lower urinary tract (LUT) functions.

Materials and Methods: The study included 286 adult patients with type 1 and type 2 diabetes mellitus (DM). All patients' demographic data, diabetes-specific history, laboratory and physical examination findings were recorded. All the data were compared with uroflowmetric parameters and the scores of questionnaires used for evaluation of LUT symptoms and functions.

Results: In the presence of diabetic peripheral neuropathy (DPN), average urinary flow rate $\left(Q_{\text {ave }}\right)$, International Consultation on Incontinence Questionnaire-Short Form (ICIQ-SF) score and the Overactive Bladder-questionnaire Short Form (OAB-q SF) score were significantly affected. In the presence of stage 3 or over diabetic nephropathy (DN), ICIQ-SF score was significantly higher. Also, in elderly group, $Q_{\text {ave }}$ and OAB-q SF score were significantly affected. The $Q_{\text {ave }}$ was lower both in patients who underwent any surgery due to diabetic complications and in patients with DM-related diseases. $0_{\text {ave }}$ and OAB-q SF score were significantly lower in males. Type 2 DM was associated with postvoid residual (PVR) increase and $\mathrm{O}_{\text {ave }}$ decrease. Poor glycemic control was associated with lower OAB-q SF score. Finally, vitamin D deficiency was found to be associated with an increase in PVR volume.

Conclusion: The present study showed that DPN, stage 3 or over DN, aging, DM-related diseases and surgeries, male gender, type 2 DM, poor glycemic control and vitamin D deficiency cause a tendency to develop any kind of LUT dysfunction.

Keywords: Diabetes mellitus, Diabetic neuropathies, Lower urinary tract symptoms, Quality of life

Öz

Amaç: Bu çalışmanın amacı diyabete bağlı metabolik değişikliklerin ve kronik komplikasyonların alt üriner sistem (AÜS) fonksiyonları üzerine olan etkisini araştırmaktır.

Gereç ve Yöntem: Çalışmaya tip 1 ve tip 2 diabetes mellitus (DM) tanılı 286 erişkin hasta alındı. Tüm hastalara ait veriler retrospektif olarak tarandı. Tüm hastaların demografik bilgileri, diyabete özgü hastalık öyküleri, laboratuvar ve fizik muayene bulguları kaydedildi. Hastalara ait tüm veriler üroflovmetrik ölçüm sonuçları ve AÜS semptomu sorgu formlarından elde edilen skorlarla karşılaştırıldı.

Correspondence: Ümit Eskidemir MD, Menemen State Hospital, Clinic of Urology, İzmir, Turkiye

E-mail: dr.eskidemir@gmail.com ORCID-ID: orcid.org/0000-0002-3557-1888

Received: 18.09.2018 Accepted: 21.11.2018

Cite this article as: Eskidemir Ü, Şimşir A, Yıldırım Şimşir I, Kızılay F, Özyurt C. Evaluation of Lower Urinary Tract Functions in Diabetic Patients. J Urol Surg 2019;6(1):46-53.

Presented in: The study has previously been presented in International Continence Society 47th Annual Meeting, Florence at 12-15 September 2017 as a e-poster presentation.

๑Copyright 2019 by the Association of Urological Surgery / Journal of Urological Surgery published by Galenos Publishing House. 
Bulgular: Diyabetik periferal nöropati (DPN) varlığında ortalama idrar akım hızının ( $0_{\text {ave }}$ ), International Consultation on Incontinence QuestionnaireShort Form (ICIQ-SF) skoru ve Overactive Bladder-questionnaire Short Form (OAB-q SF) skorunun anlamlı olarak etkilendiği saptandı. Evre 3 ve üzeri diyabetik nefropati (DN) varlığında ICIQ-SF skoru anlamlı olarak yüksek saptandı. Ayrıca yaşı hasta grubunda $Q_{\text {ave }}$ ve $0 A B-q$ SF skorunun anlamlı olarak azaldığı saptandı. Diyabetik komplikasyonlar nedeniyle cerrahi geçirenlerde ve DM ile ilişkili komorbid hastalığı olanlarda $Q_{\text {ave }}$ anlamlı olarak düşük saptandı. Erkek hastalarda $Q_{\text {ave }}$ ve $O A B-q$ SF skoru anlamlı olarak düşük saptandı. Tip 2 DM'nin postvoid residual (PVR) volümde artış ve $O_{\text {ave }}$ 'da azalma ile ilişkili olduğu saptandı. Kötü glisemik kontrolün $O A B-q$ SF skorunda düşüş ile ilişkili olduğu gösterildi. Son olarak D vitamini eksikliğinin PVR volümde artış ile ilişkili olduğu saptandı.

Sonuç: Çalışmamızda DPN, evre 3 ve üzeri DN, ileri yaş, diyabetik komplikasyonlar nedeniyle geçirilmiş cerrahiler, DM ile ilişkili komorbid hastalıklar, erkek cinsiyet, tip 2 DM, kötü glisemik kontrol ve D vitamini eksikliği faktörlerinin diyabetik hastalarda AÜS disfonksiyonu gelişimine yatkınlık oluşturduğu saptanmıştır.

Anahtar Kelimeler: Diabetes mellitus, Diyabetik nöropati, Alt üriner sistem semptomları, Hayat kalitesi

\section{Introduction}

Diabetes mellitus (DM), which has an increased prevalence and common complications, is a serious health problem all over the world. It has many unfavourable effects on the lower urinary tract (LUT) due to being a systemic disease. It results in a wide spectrum of LUT symptoms (LUTS) with several pathophysiological mechanisms. The frequent symptoms are overactive bladder syndrome and detrusor dysfunction. It is believed that alterations in the severity and frequency of these symptoms are related to DM and its chronic complications $(1,2,3,4,5,6)$. The aim of this study was to investigate the relationship between physio-pathological changes related to DM and LUT dysfunction.

\section{Materials and Methods}

A total of 286 patients with the diagnosis of type 1 and type 2 DM, who had been followed between January 2013 and January 2016 in the department of endocrinology at Ege University Faculty of Medicine, were enrolled in our study. One hundred and eighty six patients with the diagnosis of urethral stricture, bladder stone, benign prostatic hyperplasia (BPH), genitourinary infection or inflammation, previous genitourinary surgery, genitourinary radiation, urinary diversion, genitourinary malignancy or a neurologic condition were excluded. Data of 100 patients were analysed retrospectively. Age, sex and body mass index (BMI) were recorded as demographic parameters (Table 1). Type of DM, duration of DM, presence of DM-related diseases, previous surgery related to diabetic complications, presence of diabetic peripheral neuropathy (DPN), presence of diabetic nephropathy $(D N)$, and presence of diabetic retinopathy (DR) were recorded as clinical parameters (Table 2). Fasting plasma glucose (FPG), serum glycosylated hemoglobin ( $\mathrm{HbA1c}$ ), serum vitamin D levels and calculated glomerular filtration rate (GFR) from serum creatinine were recorded as laboratory parameters (Table 3 ). Voided volume, average flow rate $\left(0_{\text {ave }}\right)$ and postvoid residual
(PVR) volume were recorded as uroflowmetric parameters. International Prostate Symptom Score (IPSS), International Consultation on Incontinence Questionnaire-Short Form (ICIQ$\mathrm{SF}$ ) and Overactive Bladder-questionnaire Short Form (OAB-q SF) scores were recorded as query form scores.

The voiding pattern, $Q_{\text {ave' }}$ the voided volume and the PVR volume were taken into account when assessing the voiding functions of the patients. A PVR volume of less than $50 \mathrm{~mL}$ with appropriate flow rate was considered normal. Patients having a PVR volume of greater than $100 \mathrm{~mL}$ were considered to have diabetic bladder dysfunction (DBD). A cut-off value of a PVR volume greater than $50 \mathrm{~mL}$ but less than $100 \mathrm{~mL}$ and a bladder voiding efficiency (BVE) of less than $75 \%$ was used to identify patients with DBD (7). Using the voided volume and PVR volume, the BVE was calculated as follows: BVE $=100 \%$ voided volume/ (voided volume + PVR) (8). The conditions of the patients in terms of LUTS were evaluated using the Turkish version of the IPSS $(9,10,11,12)$. The IPSS was used for quantification of the symptoms in diabetic patients, although it was developed to quantify LUTS in patients with BPH. However, it is well known that IPSS is not BPH-specific, and it is not unreasonable to use the IPSS for quantification of LUTS in diabetic patients (13). Patients with a IPSS score of $\geq 8$ were considered to have clinically significant LUTS (14). The ICIO-SF and OAB-q SF questionnaires were used for evaluation of overactive bladder

Table 1. Demographic data of participants

\begin{tabular}{llll}
\hline Parameter & & Values, $\mathbf{n}(\%)$ & Mean \pm SD \\
\hline Age (years) & $18-54$ & $52(52)$ & $50.5 \pm 16.6$ \\
\cline { 2 - 3 } & $55-85$ & $48(48)$ & \\
\hline Gender & Male & $38(38)$ & - \\
\cline { 2 - 3 } & Female & $62(62)$ & \\
\hline BMI $\left(\mathrm{kg} / \mathrm{m}^{2}\right)$ & $<25$ & $38(38)$ & $28.5 \pm 8.3$ \\
& $25-29.9$ & $28(28)$ & \\
& $\geq 30$ & $34(34)$ & \\
\hline
\end{tabular}

BMI: Body mass index, SD: Standard deviation 
syndrome and urinary incontinence (UI). The patients were divided into two groups according to age. The threshold age was set to 55 years (15). The threshold for long-term DM and short-term DM was set to 15 years (16). BMI was calculated by dividing weight in kilograms by height in meters squared for each participant $\left[\mathrm{BMI}=\right.$ weight $(\mathrm{kg}) /$ height $\left.\left(\mathrm{m}^{2}\right)\right]$. Patients with a BMI of $<25 \mathrm{~kg} / \mathrm{m}^{2}$ were considered normal, those with a BMI between $25-29.9 \mathrm{~kg} / \mathrm{m}^{2}$ were considered overweight and those with a BMI of $\geq 30 \mathrm{~kg} / \mathrm{m}^{2}$ were considered obese (17). Patients with a FPG of $\leq 130 \mathrm{mg} / \mathrm{dL}$ and/or a $\mathrm{HbA} 1 \mathrm{c}$ value of $\leq 7 \%$ have achieved the glycaemic control goals, thus they were considered well-controlled diabetic patients (18). The incidence of diabetic complications is significantly increased in patients with a GFR of $<60 \mathrm{~mL} / \mathrm{min} / 1.73 \mathrm{~m}^{2}$ (stage 3 or over DN) (18). Therefore, in our study, our patients were divided into two groups: those with a GFR $<60 \mathrm{~mL} / \mathrm{min} / 1.73 \mathrm{~m}^{2}$ and GFR $\geq 60 \mathrm{~mL} / \mathrm{min} / 1.73 \mathrm{~m}^{2}$. GFR was calculated using the Cockroft-Gault formula (calculated creatinine clearance $=[(140$-age $) \times 1.23 \times$ body weight $(\mathrm{kg}) /$ serum creatinine $(\mathrm{mg} / \mathrm{dL})] \times 0.85$ if female) (19). The presence of DPN was determined by $10-\mathrm{g}$ monofilament test. Sensory evaluation was made by pressing on the three points of the sole of both feet (the thumb and the first and the fifth metatarsals) until the monofilament becomes " $\mathrm{C}$ " shaped. Detection of sensation loss at one or more points was considered loss of protective sensation (18). Presence of DR was determined by indirect ophthalmoscopy and all patients with pre-proliferative $D R$, proliferative $D R$ and macular edema were considered to have any kind of DR (18). Patients with a vitamin D level of $>20$ $\mathrm{ng} / \mathrm{mL}$ were considered normal, those with a level $10-20 \mathrm{ng} / \mathrm{mL}$ were considered with vitamin $D$ insufficiency and those with a level of $<10 \mathrm{ng} / \mathrm{mL}$ were considered with vitamin $D$ deficiency $(20,21,22)$. Macrovascular diseases, such as coronary artery disease, peripheral artery disease and carotid artery disease, were considered as having DM-related diseases. Major surgeries, such as coronary artery by-pass grafting and amputation, were considered surgeries that may be associated with diabetic complications.

The statistical analysis was performed by comparing all the recorded data of the patients having uroflowmetry measurement values, PVR volume, IPSS scores, ICIQ-SF scores and OAB-q SF scores.

\section{Statistical Analysis}

First of all, the frequency tables were prepared and then the numbers and the percentages belonging to all variables were put in tables. The descriptive statistical data were calculated for continuous variables. The cross-tabulation and the chi-square analysis were used for the analysis of the categorical variables. It was understood that variables that were smaller than the $p$ value of 0.05 were not normally distributed in the ShapiroWilk normality test. For this reason, the Spearman's correlation coefficient was used in the analysis of the correlation for the continuous variables. The Mann-Whitney $U$ test was used in order to compare two independent groups. The Kruskal-Wallis test was used for normal non-scattering variables and ANOVA for normal scattering variables. The significance level of all the hypothesis tests was 0.05 . For the statistical analysis, IBM SPSS statistical package program version 21.0 was used.

\section{Results}

The age distribution was as follows: $52 \%$ of the patients were in the 18-54 age group, while 48\% were in the 55-85 age group. The mean age of the whole group was $50.5 \pm 16.6$ years. $62 \%$ of the patients were female and $38 \%$ were male. When the patients were grouped according to BMI, 38\% of the patients were within the normal weight range, $28 \%$ were overweight and $34 \%$ were obese. The mean BMI of all patients was $28.5 \pm 8.3$ $\mathrm{kg} / \mathrm{m}^{2}$ (Table 1). $27 \%$ of the patients were in type 1 DM group while $73 \%$ were in type 2 DM group. According to the duration of $\mathrm{DM}, 71 \%$ of the patients were in the group of short-term DM while $29 \%$ were in the group of long-term DM. The mean duration of DM was $13.2 \pm 9.2$ years. According to the presence of additional DM-related diseases, there was at least one DMrelated disease in $69 \%$ of the patients in whom 31\% had no comorbidity. 52\% of the patients did not undergo any surgical intervention owing to a diabetic complication; on the other hand, $48 \%$ of them had at least one surgical intervention due to a diabetic complication. With respect to the neurological examination, 59\% of the patients were found to be normal and $41 \%$ of them had DPN. With respect to the GFR value, it was

Table 2. Clinical parameters of participants

\begin{tabular}{|c|c|c|c|}
\hline Parameter & & Values, n (\%) & Mean \pm SD \\
\hline \multirow[t]{2}{*}{ Type of DM } & Type 1 DM & 27 (27) & - \\
\hline & Type 2 DM & $73(73)$ & \\
\hline \multirow{2}{*}{$\begin{array}{l}\text { Duration of DM } \\
\text { (years) }\end{array}$} & $1-15$ & $71(71)$ & $13.2 \pm 9.2$ \\
\hline & $>15$ & $29(29)$ & \\
\hline \multirow[t]{2}{*}{ DM-related diseases, } & No & $31(31)$ & - \\
\hline & Yes & $69(69)$ & \\
\hline \multirow[t]{2}{*}{ DM-related surgeries } & No & $52(52)$ & - \\
\hline & Yes & $48(48)$ & \\
\hline \multirow[t]{2}{*}{ Presence of DPN } & No & 59 (59) & - \\
\hline & Yes & $41(41)$ & \\
\hline \multirow{2}{*}{$\begin{array}{l}\text { Presence of DN } \\
(\geq \text { stage } 3 \text { ) }\end{array}$} & No & 87 (87) & - \\
\hline & Yes & $13(13)$ & \\
\hline \multirow[t]{2}{*}{ Presence of DR } & No & $62(62)$ & - \\
\hline & Yes & $38(38)$ & \\
\hline
\end{tabular}

DM: Diabetes mellitus, DPN: Diabetic peripheral neuropathy, DN: Diabetic nephropahy, DR: Diabetic retinopathy, SD: Standard deviation 
found that $13 \%$ of the patients had stage 3 or over DN (GFR $<60$ $\mathrm{mL} / \mathrm{min} / 1.73 \mathrm{~m}^{2}$ ) and $87 \%$ of them had stage 1 or $2 \mathrm{DN}$ (GFR $\geq 60$ $\mathrm{mL} / \mathrm{min} / 1.73 \mathrm{~m}^{2}$ ). Ophthalmologic evaluation showed that $62 \%$ of the patients were normal and 38\% of them had DR (Table 2). According to $F P G, 34 \%$ of the patients were found to have well-controlled DM (FPG 80-130 mg/dL) and 66\% were found to have poorly-controlled DM (FPG $\geq 130 \mathrm{mg} / \mathrm{dL}$ ). According to HbA1c value, $27 \%$ of the patients had achieved glycaemic control goal $(\mathrm{HbA} 1 \mathrm{c} \leq 7 \%)$ and $73 \%$ of the patients were in poor glycaemic control (HbA1c $>7 \%$ ) group. $67 \%$ of the patients had vitamin D deficiency, 17\% had vitamin D insufficiency and 16\% had normal vitamin D levels (Table 3).

The PVR measurement results showed that $65 \%$ of the patients had a PVR volume $<50 \mathrm{~mL}$, 19\% had PVR volume between 50 $\mathrm{mL}$ and $100 \mathrm{~mL}$ and $16 \%$ had a PVR volume $>100 \mathrm{~mL}$. According to the DBD status, $79 \%$ of the patients did not have voiding dysfunction and 21\% had DBD. According to the IPSS score, $55 \%$ of the patients had clinically significant LUTS while $45 \%$ had no clinically significant LUTS (Table 4). The mean ICIQ-SF score was $3.4 \pm 5$.2. The mean ICIQ-SF quality of life $(\mathrm{QoL})$ score was $1.4 \pm 2.7$. The mean $O A B-q$ SF symptom severity score was $27.5 \pm 21.0 \%$ and the mean OAB-q SF QoL score was $81.6 \pm 18.8 \%$.

Table 3. Laboratory parameters of participants

\begin{tabular}{llll}
\hline Parameter & & $\begin{array}{l}\text { Values, } \mathbf{n} \\
(\%)\end{array}$ & Mean \pm SD \\
\hline FPG (mg/dL) & $80-130$ & $34(34)$ & $172.3 \pm 73.9$ \\
& $>130$ & $66(66)$ & \\
\hline HbA1c (\%) & $\leq 7$ & $27(27)$ & $8.8 \pm 2.4$ \\
& $>7$ & $73(73)$ & \\
\hline Vitamin D (ng/mL) & $<10$ & $67(67)$ & $25.4 \pm 26.4$ \\
& $10-20$ & $17(17)$ & \\
\hline GFR (mL/min/1.73 & $>20$ & $16(16)$ & \\
$\left.\mathrm{m}^{2}\right)$ & $<60$ & $13(13)$ & $110.5 \pm 43.2$ \\
\hline
\end{tabular}

FPG: Fasting plasma glucose, HbA1c: Serum glycosylated hemoglobin, GFR: Glomerular filtration rate, SD: Standard deviation

Table 4. Postvoid residual, diabetic bladder dysfunction status and International Prostate Symptom Scores of participants

\begin{tabular}{llll}
\hline Parameter & & Values, $\mathbf{n}(\%)$ & Mean \pm SD \\
\hline PVR $(\mathrm{mL})$ & $<50$ & $65(65)$ & \\
& $50-100$ & $19(19)$ & $60.9 \pm 101.0$ \\
& $>100$ & $16(16)$ & \\
\hline DBD & No & $79(79)$ & - \\
& Yes & $21(21)$ & \\
\hline IPSS & $0-7$ & $45(45)$ & \\
& $8-19$ & $42(42)$ & $9.6 \pm 7.2$ \\
& $20-35$ & $13(13)$ & \\
\hline
\end{tabular}

PVR: Postvoid residual, DBD: Diabetic bladder dysfunction, IPSS: International Prostate Symptom Score, SD: Standard deviation
When the presence of DPN was evaluated, $0_{\text {ave }}$ in the DPN presence was found to be $34 \%$ lower $(p<0.05)$. Again, in the presence of DPN, the ICIQ-SF total score was found to be 2.1 times higher than in the non-DPN group ( $p=0.015)$. ICIQ-SF QoL score was significantly higher in DPN group $(p=0.038)$. In the presence of DPN, the OAB-q SF symptom severity score was 1.4 times higher than in the non-DPN group ( $p=0.022)$. In addition, in the presence of DPN, the OAB-q SF OoL score was $12 \%$ lower than in the non-DPN group ( $p=0.003)$.

When the GFR-related data were analysed, the ICIQ-SF total score was significantly higher in the group with low GFR $(p=0.020)$. Also, the ICIQ-SF QoL score was significantly higher in the group with low GFR, thus, the QoL was significantly worse $(p=0.011)$.

When the age-related parameters were examined, $0_{\text {ave }}$ was found to be $24 \%$ lower in the elderly group than in the younger group ( $p=0.008$ ). In addition, the OAB-q SF symptom severity score was significantly increased $(p=0.007)$ and the OAB-q SF OoL score was significantly decreased $(p=0.002)$ in the elderly group.

When the history of surgeries related to diabetic complications was assessed, $Q_{\text {ave }}$ was $24 \%$ lower in patients who underwent surgery due to diabetic complications $(p=0.010)$. In addition, DBD was found to be 4.7 times more frequent in the group with a history of surgery ( $p=0.006)$. Also, $Q_{\text {ave }}$ was found to be $26 \%$ lower in patients with additional DM-related disease $(p=0.010)$.

When the gender-related parameters were examined, it was found that $Q_{\text {ave }}$ in male patients was 34\% lower than that in females $(p<0.05)$. In addition, the OAB-q SF QoL score in male patients was found to be significantly lower than in females $(p=0.035)$.

In terms of type of DM, it was found that type 2 DM was significantly associated with PVR increase $(p=0.047) .0_{\text {ave }}$ was also $26 \%$ lower in the patients with type 2 DM ( $p=0.003)$.

According to the results of $\mathrm{HbA1c}$ analysis, the OAB-q SF OoL score was found to be $10 \%$ lower in the high HbA1c group $(p=0.026)$. According to the results of analysis on vitamin $D$, PVR was significantly higher in the group with vitamin $D$ deficiency ( $p=0.006$ ) (Table 5).

\section{Discussion}

The main goal of our study was to investigate the relationship between DM and LUT functions which has been investigated by many authors $(3,4,6,23)$. The generally accepted view in this regard is that pathologies caused by DM at the microvascular level, as well as DM-related metabolic changes, affect LUT functions in a certain way. DM causes changes in the mass, 
Table 5. Parameters associated with lower urinary tract functions

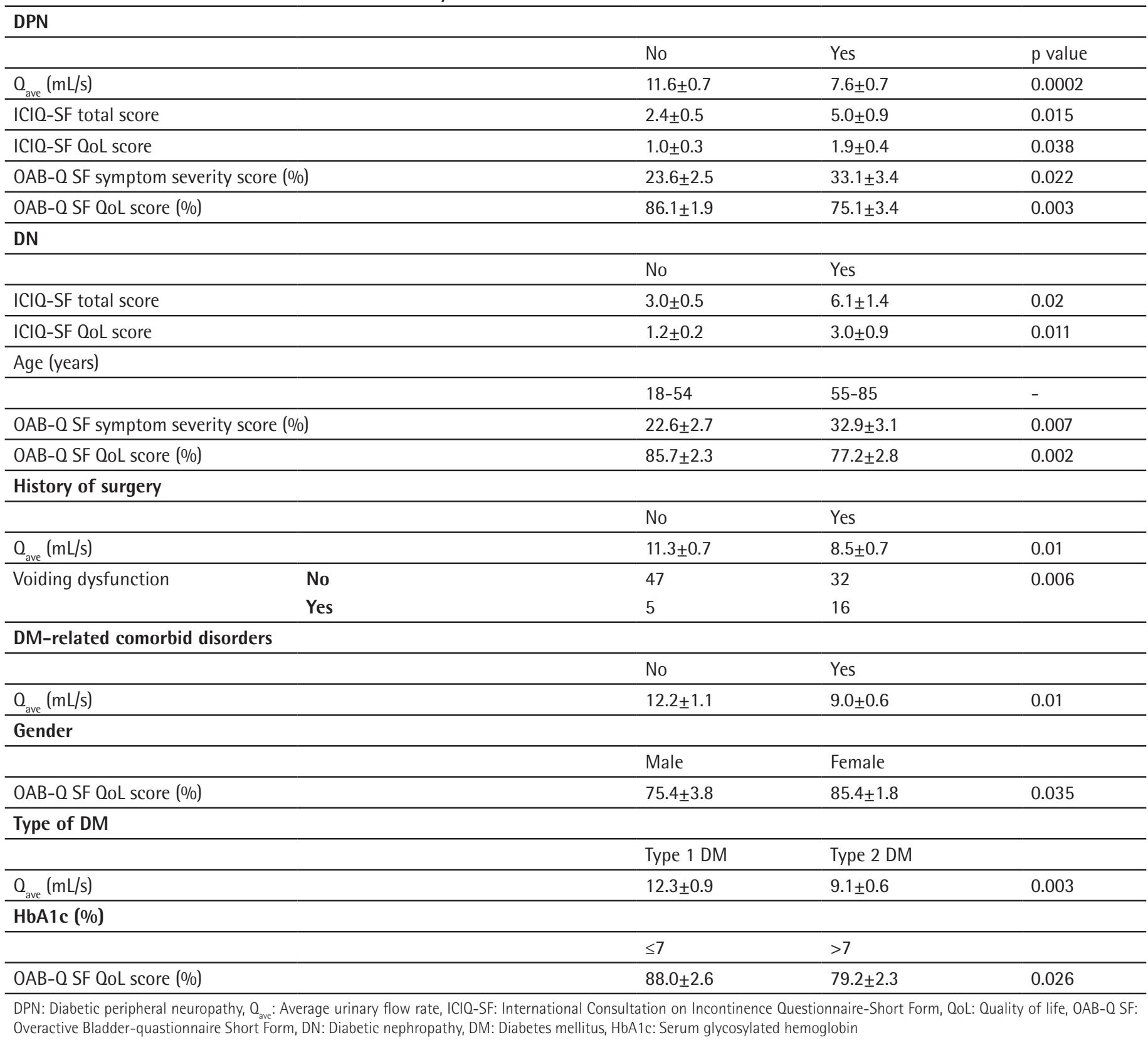

compliance and parenchyma composition of bladder tissue (24). The main pathologies that have been most searched and associated with DM are OAB syndrome, detrusor hyporeflexia, detrusor areflexia, urge incontinence and stress UI. These pathologies can be put under the diabetic cystopathy (DC) framework.

In diabetic patients, LUTS is insidious and often patients with DC do not notice this. Most of these patients show delayed clinical presentation after decompensation has developed (25). However, in diabetic patients, LUT dysfunction may also occur without LUTS, and LUTS alone may not be used to predict diabetic LUT dysfunction (13). Liu and Daneshgari (24) have detected that more than $50 \%$ of diabetic patients had LUT dysfunction although they were asymptomatic. DC is a condition that must be detected before it becomes symptomatic because it has an insidious onset and it causes many permanent anatomical and functional disorders until it becomes symptomatic (26).

It is well known that one of the most important factors in the etiopathogenesis of DC is DPN. DM is a disease that causes peripheric and autonomic neuropathy over time and eventually it ends up with deterioration of LUT functions. In a study by Bansal et al. (1) published in 2011, a significant relationship between electrophysiologically proven DPN and urodynamically proven DC was reported. In our study, the pathology which had 
the strongest relationship with LUT dysfunction was found to be DPN. Our statistical analysis showed that $Q_{\text {ave }}$ was $34 \%$ lower in the DPN presence $(p<0.05)$. Again, in the presence of DPN, the ICIQ-SF total score was found to be 2.1 times higher than in nonDPN group ( $\mathrm{p}=0.015)$ and IClO-SF QoL score was significantly higher in the DPN group ( $p=0.038$ ). Also, our study showed that in the presence of DPN, the OAB-q SF symptom severity score was 1.4 times higher than in the non-DPN group ( $p=0.022)$. In addition, in the presence of DPN, the OAB-q SF QoL score was $12 \%$ lower than in the non-DPN group $(\mathrm{p}=0.003)$. According to these results, very strong evidence has been obtained by showing the relationship between DPN and LUT dysfunction.

The relationship between DN and LUTS is another issue being investigated in the literature. In patients with DM-related complications, such as retinopathy or nephropathy, the incidence of LUTS has been reported to be $20 \%$ higher than in patients without complications (27). In our study, when GFR-related data were analysed, the ICIQ-SF total score was significantly higher in the group with low GFR ( $p=0.020)$. Also, ICIQ-SF QoL score was significantly higher in the group with low GFR, indicating that the $\mathrm{OoL}$ was significantly worse $(p=0.011)$. According to these findings, it can be said that stage 3 or over DN creates a tendency to $\mathrm{UI}$ in these patients and severely impairs QoL.

Age is one of the demographic parameters that may be closely associated with LUT functions in diabetic patients. In our study $0_{\text {ave }}$ was found to be $24 \%$ lower in the elderly group than in the younger group ( $p=0.008$ ). In addition, the $0 A B-q$ SF symptom severity score was significantly increased $(p=0.007)$ and the OAB-q SF QoL score was significantly decreased $(p=0.002)$ in the elderly group. Liu et al. (28) showed that the prevalence of OAB was 2.4-4.2 times higher in type 2 DM patients who were older than 50 years. Also, Bani-issa et al. (2) showed that age, duration of DM and obesity were the most significant risk factors for all types of UI.

DM-related diseases and surgical interventions related to diabetic complications are the signs of the poorly controlled DM. In our study $Q_{\text {ave }}$ was found to be $26 \%$ lower in patients with additional DM-related diseases $(p=0.010)$. Also, $0_{\text {ave }}$ was $24 \%$ lower in patients who underwent surgery due to diabetic complications $(p=0.010)$. In addition, DBD was found to be 4.7 times more frequent in the group with surgical history $(p=0.006)$. Based on our findings, it can be assumed that surgical interventions due to a diabetic complication and the presence of DM-related diseases may be significant predictors of LUT dysfunction.

The prevalence of vitamin D deficiency in diabetic patients was evaluated by Al-Timimi and Ali (32) in a study conducted in
2013. They found that low vitamin D levels were found in $2 / 3$ of patients with poor glycaemic control and prolonged type 2 DM. Similarly, Isaia et al. (33) reported that vitamin D deficiency was more common in diabetic patients. Our results showed that $67 \%$ of the patients had vitamin D deficiency, 17\% of them had vitamin D insufficiency and $16 \%$ of them had normal vitamin D levels. PVR was significantly higher in the group with vitamin $D$ deficiency ( $p=0.006)$. It is known that high PVR is an important cause of LUTS and it is the result of many LUT dysfunctions. According to our findings, it can be said that vitamin D deficiency has a significant effect on LUT functions.

The duration of DM is an important predictive factor for microvascular and macrovascular complications of DM (18). Several reports showed a relationship between duration of DM and LUTS. Bani-issa et al. (2) showed that longer duration of DM was associated with $\mathrm{UI}$ in type 2 diabetic women. Yu et al. (34) showed that a duration of DM $\geq 20$ years was associated with voiding difficulty in female patients. Also Beylot et al. (35) showed that the duration of DM increased the risk of UI. Although our results did not show a significant association between the duration of DM and any kind of LUTS, there is strong evidence in the literature on this issue. The reason for the insignificant finding regarding the association between the duration of DM and any kind of LUTS in our study may be the limited number of patients involved.

\section{Study Limitations}

The limiting factors in our study can be put forward as the retrospective design and relatively limited number of patients.

\section{Conclusion}

The results obtained from our study showed that presence of DPN and a DN higher than stage 2, age $\geq 55$, previous surgery history related to diabetic complications, presence of DM-related diseases, male gender, diagnosis of type 2 DM, poor glycaemic control and presence of vitamin D deficiency were the predisposing factors for developing any kind of LUT dysfunction in diabetic patients. Finally, we recommend that evaluation of LUT should be done as a routine part of evaluation for diabetic patients considering the risk factors even if they are asymptomatic. The guidelines on DM management should pay more attention on this issue.

\section{Ethics}

Ethics Committee Approval: Retrospective study.

Informed Consent: Due to retrospective nature of the study, no written informed consent was obtained from the patients.

Peer-review: Externally peer-reviewed. 


\section{Authorship Contributions}

Concept: A.Ş., I.Y.Ş., C.Ö., Design: A.Ş., I.Y.Ş., Data Collection or Processing: Ü.E., I.Y.Ş., Analysis or Interpretation: Ü.E., F.K., Literature Search: Ü.E., A.Ş., Writing: Ü.E.

Conflict of Interest: No conflict of interest was declared by the authors.

Financial Disclosure: The authors declared that this study received no financial support.

\section{References}

1. Bansal R, Agarwal MM, Modi M, Mandal AK, Singh SK. Urodynamic profile of diabetic patients with lower urinary tract symptoms: Association of diabetic cystopathy with autonomic and peripheral neuropathy. Urology 2011;77:699-705.

2. Bani-issa W, Fakhry R, Al Momani F. Urinary incontinence in Emirati women with diabetes mellitus type 2: Prevalence, risk factors and impact on life. J Clin Nurs 2013;22:3084-3094.

3. Yu H-J, Lee W-C, Liu S-P, Tai T-Y, Wu H-P, Chen J. Unrecognized voiding difficulty in female type 2 diabetic patients in the diabetes clinic: a prospective case-control study. Diabetes Care 2004;27:988-989.

4. Tai H-C, Chung S-D, Ho C-H, Tai T-Y, Yang W-S, Tseng C-H, Wu HP, Yu HJ. Metabolic syndrome components worsen lower urinary tract symptoms in women with type 2 diabetes. J Clin Endocrinol Metab 2010;95:1143-1150.

5. Kebapci N, Yenilmez A, Efe B, Entok E, Demirustu C. Bladder dysfunction in type 2 diabetic patients. Neurourol Urodyn 2007;26:814-819.

6. Van Den Eeden SK, Ferrara A, Shan J, Jacobsen SJ, Quinn VP, Haque R, Quesenberry CP. Impact of type 2 diabetes on lower urinary tract symptoms in men: a cohort study. BMC Urol 2013;13:12.

7. Lee $\mathrm{W}-\mathrm{C}, \mathrm{Wu} \mathrm{C}-\mathrm{C}, \mathrm{Wu} \mathrm{H}-\mathrm{P}, \mathrm{Tai} \mathrm{T}-\mathrm{Y}$. Lower urinary tract symptoms and uroflowmetry in women with type 2 diabetes mellitus with and without bladder dysfunction. Urology 2007;69:685-690.

8. Abrams P. Bladder outlet obstruction index, bladder contractility index and bladder voiding efficiency: three simple indices to define bladder voiding function. BJU Int 2016;84:14-15.

9. Çetinel B, Özkan B, Can G. Türk Üroloji Dergisi. 2004;30:332-338.

10. Bozlu M, Doruk E, Akbay E, Ulusoy E, Çayan S, Acar D, Kanik EA. Effect of administration mode (patient vs physician) and patient's educational level on the Turkish version of the International Prostate Symptom Score. Int J Urol 2002;9:417-421.

11. Tarcan T, Mangir N, Özgür MO, Akbal C. OAB-V8 Aşırı Aktif Mesane Sorgulama Formu Validasyon Çalışması. Üroloji Bülteni 2012;21:113-116.

12. Acquadro C, Kopp Z, Coyne KS, Corcos J, Tubaro A, Choo MS. Translating overactive bladder questionnaires in 14 languages. Urology 2006;67:536540.

13. Mitsui $T$, Kakizaki $H$, Kobayashi $S$, Morita $H$. Vesicourethral Function in Diabetic Patients: Association of Abnormal Nerve Conduction Velocity With Vesicourethral Dysfunction. Neurourol Urodyn 1999;645:639-645.

14. Barbosa JABA, Muracca $E$, Nakano $E$, Paranhos $M$, Natalino $R$, Cordeiro $P$, Srougi $M$, Antunes AA. Risk factors for male lower urinary tract symptoms: the role of metabolic syndrome and androgenetic alopecia in a Latin American population. Urology 2013;82:182-188.
15. Fredrick T, Kaur P, Murhekar M V, Jayaraman Y, Kolandaswamy K, Rao SR, David JK. Diabetic retinopathy and its risk factors in patients with type 2 diabetes attending rural primary healthcare facilities in Tamil Nadu. Natl Med J India 2016;29:9-13.

16. Obirikorang Y, Obirikorang C, Anto EO, Acheampong E, Batu EN, Stella AD, Constance O, Brenya PK. Knowledge of complications of diabetes mellitus among patients visiting the diabetes clinic at Sampa Government Hospital, Ghana: a descriptive study. BMC Public Health 2016;16:637.

17. National Heart, Lung and Blood Institute. Classification of Overweight and Obesity by BMI, Waist Circumference, and Associated Disease Risks. Available from: https://www.nhlbi.nih.gov/health/educational/lose_wt/ BMI/bmi_dis.htm

18. Diabetes Mellitus Çalışma ve Eğitim Grubu. Diabetes Mellitus ve Komplikasyonlarının Tanı, Tedavi ve İzlem Kılavuzu, 2016, pp 16-18.

19. Stojceva-Taneva O, Otovic NE, Taneva B. Prevalence of Diabetes Mellitus in Patients with Chronic Kidney Disease. Open Access Maced J Med Sci 2016;15:79-82.

20. Lamberg-Allardt C, Brustad M, Meyer HE, Steingrimsdottir L. Vitamin D - a systematic literature review for the 5th edition of the Nordic Nutrition Recommendations. Food Nutr Res 2013:57.

21. Looker AC, Johnson CL, Lacher D, Pfeiffer CM, Schleicher RL, Sempos CT. Vitamin D status: United States, 2001-2006. NCHS Data Brief 2011;127:1-8.

22. Ross AC, Manson JE, Abrams SA, Aloia JF, Brannon PM, Clinton SK, DurazoArvizu RA, Gallagher JC, Gallo RL, Jones G, Kovacs CS, Mayne ST, Rosen CJ, Shapses SA. The 2011 report on dietary reference intakes for calcium and vitamin D from the Institute of Medicine: what clinicians need to know. $J$ Clin Endocrinol Metab 2011;96:53-58.

23. Sarma AV, Kellogg Parsons J. Diabetes and benign prostatic hyperplasia: emerging clinical connections. Curr Urol Rep 2009;10:267-275.

24. Liu G, Daneshgari F. Alterations in neurogenically mediated contractile responses of urinary bladder in rats with diabetes. Am J Physiol Renal Physiol 2005;288:1220-1226.

25. Frimodt-Møller C. Diabetic cystopathy. A review of the urodynamic and clinical features of neurogenic bladder dysfunction in diabetes mellitus. Dan Med Bull 1978;25:49-60.

26. Kokulu K, Türkyılmaz R, Özkeçeli R, Erken U. Diabetik sistopatide sistometri. Turk J Urol 1984;10:199-206.

27. Wiedemann A, Meziane N, Hirsch J, Füsgen I. [Men with type 2 diabetes and erectile dysfunction are a particular risk group for LUTS - results of the Witten Diabetes Survey]. Aktuelle Urol 2013;44:280-284.

28. Liu RT, Chung MS, Lee WC, Chang SW, Huang ST, Yang KD, Chancellor MB, Chuang YC. Prevalence of overactive bladder and associated risk factors in 1359 patients with type 2 diabetes. Urology 2011;78:1040-1045.

29. Wessells H, Braffett BH, Holt SK, Jacobson AM, Kusek JW, Cowie C, Dunn RL, Sarma AV; DCCT/EDIC Study Group. Burden of Urological Complications in Men and Women With Long-standing Type 1 Diabetes in the Diabetes Control and Complication Trial/Epidemiology of Diabetes Interventions and Complications Cohort. Diabetes Care 2018;41:2170-2177.

30. Diabetes Control and Complications Trial Research Group, Nathan DM, Genuth S, Lachin J, Cleary P, Crofford O, Davis M, Rand L, Siebert C. 
The effect of intensive treatment of diabetes on the development and progression of long-term complications in insulin-dependent diabetes mellitus. N Engl J Med 1993;329:977-986.

31. Brown JS, Nyberg LM, Kusek JW, Burgio KL, Diokno AC, Foldspang A, Fultz NH, Herzog AR, Hunskaar S, Milsom I, Nygaard I, Subak LL, Thom DH; National Institute of Diabetes and Digestive Kidney Diseases International Research Working Group on Bladder Dysfunction. Proceedings of the National Institute of Diabetes and Digestive and Kidney Diseases International Symposium on Epidemiologic Issues in Urinary Incontinence in Women. Am J Obstet Gynecol 2003;188:77-88.
32. Al-Timimi DJ, Ali AF. Serum 25(OH) D in Diabetes Mellitus Type 2: Relation to Glycaemic Control. J Clin Diagn Res 2013;7:2686-2688.

33. Isaia G, Giorgino R, Adami S. High prevalence of hypovitaminosis D in female type 2 diabetic population. Diabetes Care 2001;24:1496.

34. Yu HJ, Lee WC, Liu SP, Tai TY, Wu HP, Chen J. Unrecognized Voiding Difficulty in Female Type 2 Diabetic Patients in the Diabetes Clinic: A prospective case-control study. Diabetes Care 2004;27:988-989.

35. 35. Beylot $M$, Marion $D$, Noel G. Ultrasonographic determination of residual urine in diabetic subjects: relationship to neuropathy and urinary tract infection. Diabetes Care 1982;5:501-505. 